blood pressure was $220 / 170 \mathrm{~mm} \mathrm{Hg}$, he had grade IV hypertensive retinopathy, and the serum creatinine level was $5.0 \mathrm{mg} / 100 \mathrm{ml}$. He still felt well. Diazoxide $300 \mathrm{mg}$ intravenously lowered the blood pressure, but methyldopa, debrisoquin, reserpine, and clonidine failed to maintain control. There was pronounced orthostatic hypotension, but the blood pressure in the lying posture was high. Renal biopsy showed severe hypertensive nephropathy with many hyalinized glomeruli, the serum creatinine rose to $11.3 \mathrm{mg} / 100 \mathrm{ml}$, and there were bouts of left ventricular failure. It was decided to perform bilateral nephrectomy, and an infusion of sodium nitroprusside readily controlled the blood pressure (Table II). At the time of writing he was awaiting a renal transplant and his blood pressure was under control without drugs.

Case 4.-A 48-year-old man had a 10-month history of hypertension and renal failure. Control of hypertension had become in creasingly difficult, and on admission the blood pressure was 230/ $150 \mathrm{~mm} \mathrm{Hg}$, the serum creatinine $13.0 \mathrm{mg} / 100 \mathrm{ml}$, and there was a grade IV hypertensive retinopathy. Pentolinium, $25 \mathrm{mg}$ subcutaneously in 12 hours, had no effect on the blood pressure, but it fell briefly to $90 / 70 \mathrm{~mm} \mathrm{Hg}$ after $300 \mathrm{mg}$ of diazoxide intravenously. Sodium nitroprusside was then used with good effect. It was continued during peritoneal dialysis preparatory to bilateral nephrectomy, but there were pronounced swings in blood pressuresystolic 80-260, mean 156 (S.D.43); diastolic 50-160, mean 112 (S.D.28)-with severe anginal pain. There was no evidence of myocardial infarction. Sodium nitroprusside was continued after dialysis ended and blood pressure control again became satisfactory and the anginal pain ceased. After bilateral nephrectomy his blood pressure returned to normal without further therapy, but unfortunately he died six days after the operation from bronchopneumonia and septicaemia.

\section{Discussion}

Sodium nitroprusside has a direct depressant effect on vascular musculature, independent of the nervous system (Page et al., 1955). The effect is immediate and ends when the infusion is stopped. The latter property is of special value in patients in whom the cause of hypertension is to be abruptly removed. I have not used the drug during surgery for a phaeochromocytoma, but it would seem to be the drug of choice for this purpose and for when controlled lowering of blood pressure is needed during surgery. Though it is less effective in normotensive subjects than in hypertensives it produces a fall of blood pressure, and Kaneko et al. (1967) used it rapidly to lower the blood pressure in normotensive subjects to study renin release.

The drug is virtually non-toxic during short-term use. Long-term toxic effects are due to accumulation of thiocyanate, to which sodium nitroprusside is converted. One case reported by Nourok et al. (1964) developed high serum levels of thiocyanate and features of hypothyroidism after 21 days, which improved when the nitroprusside infusion was stopped. The longest period of infusion in my cases was 48 hours, and no toxic effects were observed. The swinging blood pressure and anginal pain in Case 4 were undoubtedly associated with peritoneal dialysis.

We have here an effective, safe, cheap, and readily available agent for the treatment of hypertensive emergencies. An obvious reason why it has not been more generally used is its potency and the care which must be taken during its administration, especially during the first few minutes until the correct rate of infusion is arrived at. This is not a real objection to the use of an agent with so many advantages.

I am indebted to the registrars, residents, and nursing staff of the renal unit of Sydney Hospital, whose hard work and careful attention made the use of the drug possible, and to Dr. J. H. Stewart, who was an unfailing source of encouragement.

\section{References}

Gifford, R. W. (1970). In Drugs of Choice, 1970-71, ed. W. Modell, p. 386. Saint Louis, Mosby

Kaneko, Y., Ikeda, T., Takeda, T., and Ueda, H. (1967). fournal of Clinical Investigation, 46, 705 .

Nourok, D. S., Glassock, R. J., Solomon, D. H., and Maxwell, M. H. (1964). American fournal of the Medical Sciences, 248, 129.

Page, I. H., Corcoran, A. C., Dustan, H. P., and Koppanyi, T. (1955). Circulation, 11, 188.

Stokes, G. S., Mani, M. K., and Stewart, J. H. (1970). British Medical fournal, 3, 126.

\title{
Infections of Scribner and Brescia Arteriovenous Shunts
}

\author{
A. J. RALSTON, \\ G. R. HARLOW, \\ D. M. JONES, \\ P. DAVIS
}

British Medical fournal, 1971, 3, 408-409

\section{Summary}

The incidence of infections of Scribner shunts and Brescia fistulae in patients receiving intermittent haemodialysis was compared. In both groups infection was most commonly due to Staphylococcus aureus and was associated especially with carriage of this organism on the skin of the limb where the shunt or fistula was sited. The incidence of local infection was much less with the

\section{University Hospital of South Manchester, Manchester M20 8LR}

A. J. RALSTON, M.B., M.R.C.P., Consultant Physician

G. R. HARLOW, M.B., Medical Assistant

D. M. JONES, M.D., M.R.C.PATH., Consultant Bacteriologist, Public Health Laboratory Service

P. DAVIS, F.I.M.L.T., Chief Technician
Brescia fistula but this was accompanied by a relatively higher incidence of septicaemia.

\section{Introduction}

The introduction of the Teflon arteriovenous shunt described by Scribner and his colleagues (Quinton et al., 1960) led to the treatment of chronic renal failure by intermittent haemodialysis. One of the principal complications associated with the shunt was infection (Martin et al., 1967; Curtis et al., 1969). The description of a surgically created subcutaneous arteriovenous fistula (Brescia et al., 1966) yielded an alternative method of gaining access to the circulation of the patient. Though in the original description a case of bacterial endocarditis was described, it was commonly held early on (Cohen et al., 1968; Shaldon and McKay, 1968) that one of the advantages of this technique would be the reduced incidence of infection when compared with the Scribner shunt. In this paper we describe our 
experiences of infection with both types of shunt, from January 1968 to December 1970.

Staphylococcal Carriage and Infection

\begin{tabular}{|c|c|c|c|c|c|c|c|}
\hline \multirow{2}{*}{ Group } & \multirow{2}{*}{$\begin{array}{l}\text { No. of } \\
\text { Cases }\end{array}$} & \multicolumn{2}{|c|}{ Nasal } & \multicolumn{2}{|c|}{ Shunt Limb } & \multicolumn{2}{|c|}{ Hand Skin } \\
\hline & & + & - & + & - & + & - \\
\hline $\begin{array}{l}\text { Infected } \\
\text { Non-infected }\end{array}$ & $\begin{array}{r}18 \\
8\end{array}$ & $\begin{array}{c}15(27) \\
6\end{array}$ & $\begin{array}{c}\text { cribner } S \\
3{ }_{2}(4)\end{array}$ & $\begin{array}{c}{ }_{1}^{u n t} \\
0 \\
0\end{array}$ & ${ }_{8}^{8}{ }^{(8)}$ & $9(20)$ & $9(11)$ \\
\hline $\begin{array}{l}\text { Infected } \\
\text { Non-infected }\end{array}$ & $\begin{array}{r}5 \\
32\end{array}$ & $5_{17}^{(6)}$ & $\begin{array}{c}\text { Bescia Fi } \\
0 \\
{ }_{15}(0)\end{array}$ & ${ }_{8}^{(6)}$ & $0_{24}(0)$ & $5_{8}^{(6)}$ & $0_{24}^{(0)}$ \\
\hline
\end{tabular}

Numbers in parentheses indicate numbers of episodes of infection.

\section{Method}

Patients were admitted to the unit from general wards of hospitals in the region. On the unit they were accommodated in 10 cubicles arranged along a central corridor. They remained in the unit for periods varying from 10 to 21 days before discharge home. Subsequently they attended the unit for three 10-hour haemodialyses each week for periods which varied from 3 to 11 months. At the end of this time they were dialysed in the home.

Carriage of Staphylococcus aureus was investigated by swabbing the nose, the skin area around the shunt, and the skin of the hand of the opposite limb to that carrying the shunt or fistula of all the patients monthly. The strains of Staph. aureus isolated were phage-typed and antibiotic sensitivities determined. Swabs were taken from any shunt sites showing reddening or exudate. Settle plate counts of air-borne staphylococci were performed in each cubicle and in the linking corridor on two consecutive days each month.

\section{Results}

Scribner Shunts.-Twenty-six patients had Scribner shunts in use for a total of 242 patient-months. Eighteen of them had 35 episodes of infection, an average incidence of one per 6.9 patient-months. These infections were due to Staph. aureus (31), Pseudomonas aeruginosa (1), Enterobacter aerogenes (1), coliform (1), and from one other infection no swab was taken. Sixteen of the 18 patients who had staphylococcal infections were established carriers of the relevant phage-type in various body sites (see Table). Two staphylococcal infections were of exogenous origin. Six (11\%) of the shunt infections were associated with septicaemia-Staph. aureus (4), Ps. aeruginosa (1), and $E$. aerogenes (1). All these infections were satisfactorily treated. The occurrence of shunt infection often resulted in the need to resite the shunt.

Brescia Fistulae.-Thirty-seven patients had Brescia fistulae for a total of 459 patient-months; 24 had previously had a Scribner shunt. Five patients suffered six episodes of infection requiring treatment; an average incidence of one per 76.5 patient-months. All the infections were due to Staph. aureus; the organisms being of endogenous origin. Two (33\%) infections were accompanied by septicaemia, which was successfully treated; there was no disturbance of the function of the fistula. One other patient developed what was described by her spouse as a tiny septic spot over one of the veins draining the fistula: 24 hours later she developed haemorrhage from her fistula and died on the way to the local hospital. Unfortunately we have no bacteriological information about this episode, but presume it to have been a staphylococcal skin lesion. We know of one other case where a Brescia fistula had to be ligated for haemorrhage following an infection (H. J. Goldsmith and B. J. Hawe, personal communication, 1971).

The counts of Staph. aureus on settle plates averaged 3 colonies per square metre per hour in the individual cubicles.

\section{Discussion}

The reported incidence of infection in Scribner shunts varies from one per 3.8 patient-months (Martin et al., 1967) to the remarkably low figure of one per 35 patient-months (Curtis et al., 1969). Our experience coincides with most workers that the organism commonly involved is Staph. aureus, $92 \%$ in our series, and that the organisms responsible are usually carried by the patient. The overall staphylococcal carriage rate in these patients was $50 \%$, though it was higher than this in the first weeks of training. During this initial period antibiotic-resistant strains were commonly carried, reflecting the previous hospital experience of these patients. These strains were then lost over the following months and were replaced by strains more typical of those that occur outside hospital, seldom showing resistance to antibiotics other than penicillin. We were able to observe that these strains were also often carried by the spouse, usually before they were acquired by the patient. The count of airborne staphylococci within the unit was very low, much lower than that in a well-ventilated cubicled ward (Williams and Harding, 1969). Though the cubicle design of the unit contributed to this, the short stay of the patient within the cubicle ( 36 hours weekly) and lack of mobility during dialysis were also important factors. We did not observe any acquisition of patients' strains of staphylococci by the nursing staff or by other patients.

Predictably the highest rates of shunt infection occurred in patients who carried Staph. aureus on the limb of the shunt site. The incidence of infection of the Brescia fistula (1 per 76.5 patient-months) was very much lower than the infection rate of the Scribner shunt (1 per 6.9 patient-months). The infections of the subcutaneous fistula seemed clinically less severe; despite this, two out of six infections were accompanied by septicaemia. We feel that any but the most trivial infections of the skin over the Brescia fistula should be treated promptly and energetically in view of the incidence of associated septicaemia.

We wish to thank the staff of the intermittent haemodialysis unit for collecting the specimens and Dr. J. D. Abbott for phagetyping the staphylococci.

Requests for reprints should be sent to Dr. D. M. Jones.

\section{References}

Brescia, M. J., Cimino, J. E., Appel, K., and Hurwich, B. J. (1966). New England fournal of Medicine, 275, 1009.

Cohen, S., Lidsky, I., Kest, L., Kastagir, B., and Vertes, V. (1968). Transactions. American Society for Artificial Internal Organs, 14, 421.

Curtis, J. R., et al. (1969). Quarterly fournal of Medicine, 38, 49.

Martin, A. M., Clunie, G. J. A., Tonkin, R. S., and Robson, J. S. (1967). Proceedings of the European Dialysis and Transplant Association, $4,67$. Quinton, W. Dillard, D., and Scribner, B. H. (1960). Transactions. American Society for Artificial Internal Organs, 6,104

Shaldon, S., and McKay, S. (1968). British Medical fournal, 4, 671.

Williams, R. E. O., and Harding, L. (1969). Fournal of Hygiene, 67, 649. 